\title{
Mini-Review Teknologi Carbon Capture and Utilization (CCU) Berbasis Kombinasi Proses Kimia dan Bioproses
}

\author{
Anisa Azzahra Isya ${ }^{1, a}$, Kezia Rhesa Arman ${ }^{1, b}$, Joko Wintoko ${ }^{1, c}$ \\ ${ }^{1}$ Departemen Teknik Kimia, Fakultas Teknik, Universitas Gadjah Mada, Jl. Grafika 2, Yogyakarta \\ E-mail: annisaazzahra00@mail.ugm.ac.id, bkeziarhesa00@mail.ugm.ac.id, cjwintoko@ugm.ac.id
}

\begin{abstract}
Currently, energy needs still rely on fossil fuels. On the other hand, $\mathrm{CO}_{2}$ emissions resulting from burning fossil fuels continue to increase and contribute as a greenhouse gas in the atmosphere. Global warming is a threat to the future of life. One of the countermeasures is by developing Carbon, Capture, and Utilization (CCU) technology based on a chemical absorption process to capture $\mathrm{CO}_{2}$ gas from combustion. The captured $\mathrm{CO}_{2}$ is then stored in a stable form so it will not be released into the atmosphere or used as raw material for the chemical industry. The main obstacle to implementing CCU technology on a large scale is the cost involved. Meanwhile, the revenue generated is relatively low. In CCU technology based on this chemical absorption process, chemicals as absorbents need to be regenerated and the $\mathrm{CO}_{2}$ is separated for storage or use. However, this regeneration requires a relatively high cost. Several studies have attempted to perform this regeneration with micro-algae-based bioprocesses. Micro-algae can take energy from sunlight which is abundant in tropical areas such as Indonesia. In addition, several types of micro algae have the potential to be used as food and other utilizations. This review will discuss the results of recent research on suitable chemicals for the absorption of $\mathrm{CO}_{2}$ from flue gas, its regeneration method using micro-algae, usable micro-algae species, and the potential for micro-algae utilization.
\end{abstract}

Keywords: carbon capture and utilization (CCU), chemical absorption, micro-algae

EQUILIBRIUM Volume 4 No.2 December 2020

Online at http:/ / equilibrium.ft.uns.ac.id 


\section{Pendahuluan}

\subsection{Pemanasan global dan perubahan iklim}

Carbon dioksida merupakan gas rumah kaca yang berkontribusi terhadap pemanasan global. Gas rumah kaca adalah gas-gas di atmosfer yang dapat menyerap dan memantulkan kembali radiasi infra merah dari permukaan bumi. Dalam konsentrasi yang ideal, gas rumah kaca ini menjaga suhu permukaan bumi supaya tidak terlalu jauh perbedaannya pada kondisi saat terkena sinar matahari (siang hari) dan saat tidak terkena sinar matahari (malam hari). Namun, kadar gas-gas rumah kaca, terutama $\mathrm{CO}_{2} \mathrm{di}$ atmosphere meningkat pesat sejak revolusi industri sekitar awal abad 19 saat dunia industri mulai memakai batu bara sebagai bahan bakar. Penemuan dan pemakaian minyak bumi di akhir abad 19 menambah emisi $\mathrm{CO}_{2}$ di dunia. Minyak bumi sebagai bahan bakar cair memudahkan penggunaannya di sektor transportasi di samping sebagai bahan bakar industri dan rumah tangga, sehingga pemakaiannya sangat luas. Kadar gas rumah kaca yang terus meningkat akan menahan lebih banyak panas di atmosfer sehingga suhu rata-rata permukaan bumi terus mengalami kenaikan.

Tanpa perubahan pola emisi $\mathrm{CO}_{2}$, diperkirakan suhu rata-rata permukaan bumi akan meningkat sekitar $4^{\circ} \mathrm{C}$ pada tahun 2100 dari suhu saat ini [1]. Peningkatan suhu ini akan mengakibatkan perubahan iklim secara global. Perubahan pola cuaca, perubahan curah hujan, kekeringan, gelombang udara panas, dan berbagai efek lain mengancam hampir semua sektor kehidupan manusia. Kejadian cuaca ekstrim yanga akan meningkat, produksi pertanian tanaman pangan terganggu, pasokan air menurun, kesehatan manusia terancam dengan jenis-jenis penyakit baru karena ekosistem alam berubah, dan berbagai dampak turunannya yang kompleks.

\subsection{Carbon Capture, Utilization, and Storage (CCUS)}

Upaya untuk mencegah krisis iklim akibat kenaikan suhu global ini salah satunya adalah dengan menurunkan kadar gas rumah kaca, terutama $\mathrm{CO}_{2}$ di atmosfer. Secara alami, $\mathrm{CO}_{2}$ berada dalam sebuah siklus di alam. Tanaman hijau berfotosintesis dengan bantuan sinar matahari untuk mengubah $\mathrm{CO}_{2}$ dan $\mathrm{H} 2 \mathrm{O}$ menjadi karbohidrat dan $\mathrm{O}_{2}$. Biomassa dari tanaman ini dikonsumsi oleh hewan dan manusia. Karbohidrat akan diubah kembali menjadi $\mathrm{CO}_{2}$ dan $\mathrm{H}_{2} \mathrm{O}$ oleh metabolisme dalam sel hewan dan manusia. Siklus ini seharusnya menjaga kadar $\mathrm{CO}_{2}$ selalu dalam kondisi setimbang di alam. Namun, emisi $\mathrm{CO}_{2}$ dari pembakaran bahan bakar fosil terutama minyak bumi dan batu bara mengganggu kesetimbangan ini. Karbon yang selama jutaan tahun terpendam dalam tanah, berubah menjadi $\mathrm{CO}_{2}$ di atmosfer. Kemampuan fotosintesis tumbuhan hijau di dunia tidak mampu menyerap kenaikan $\mathrm{CO}_{2}$ tersebut. Hal ini diperparah dengan deforestrasi hutan terutama di daerah tropis yang semakin menurunkan jumlah tumbuhan hijau di dunia. Tanpa intervensi manusia, kenaikan kadar $\mathrm{CO}_{2}$ ini akan semakin tak terkendali.

Teknologi yang dapat digunakan untuk menurunkan kadar $\mathrm{CO}_{2}$ di atmosfer ini secara umum dapat dibagi menjadi dua jenis yaitu: (1) teknologi untuk menurunkan kadar $\mathrm{CO}_{2}$ yang sudah ada di atmosfer dan (2) teknologi untuk mencegah atau menurunkan emisi $\mathrm{CO}_{2}$ dari aktitas industri. Secara umum kedua jenis teknologi ini disebut Carbon Capture, Utilization, and Storage (CCUS). Carbon capture adalah teknologi untuk menangkap $\mathrm{CO}_{2}$ dari gas buang hasil pembakaran bahan bakar fosil, misalnya dengan absorpsi kimia atau dengan teknologi membran. $\mathrm{CO}_{2}$ yang tertangkap alternatifnya dipergunakan sebagai bahan baku industri atau disimpan kembali ke dalam tanah sehingga tidak menambah emisi di atmosfer. Carbon utilization atau penggunaan $\mathrm{CO}_{2}$ ada yang secara langsung tanpa pengolahan misalnya untuk enhanced oil recovery (EOR) atau dengan konversi menjadi berbagai bahan kimia, material, atau bahan bakar. Sementara carbon storage adalah teknologi untuk menyimpan kembali $\mathrm{CO}_{2}$ ke dalam bumi, misalnya dengan memasukkannya kembali ke dalam reservoir minyak yang sudah habis.

Dalam review singkat ini akan dibahas khusus mengenai teknologi penangkapan $\mathrm{CO}_{2}$ dengan proses absorpsi kimia. Dengan alasan ekonomi dan lingkungan, absorben yang dipakai harus bisa diregenerasi dan dipakai ulang. Proses regenerasi ini bisa dilakukan secara fisis dengan pelucutan (stripping) memakai kukus (steam). Proses ini memerlukan energi yang besar untuk produksi kukusnya. Untuk mengurangi pemakaian erergi ini, telah diteliti penggunaan mikro-alga untuk meregenerasi absorben, sekaligus mengkonversi $\mathrm{CO}_{2}$ menjadi bahan yang bermanfaat. 


\section{Penangkapan $\mathrm{CO}_{2}$ dengan Absorpsi Kimia}

\subsection{Proses absorpsi $\mathrm{CO}_{2}$}

Absorpsi adalah proses transfer masa dari sebuah komponen atau beberapa komponen pada fase gas berpindah ke fase cair saat kedua fase berkontak. Proses ini dipengaruhi suhu dan tekanan sistem. Secara umum, semakin tinggi suhu maka semakin kecil kelarutan gas-gas dalam cairan sehingga gas yang terlarut juga semakin sedikit. Tekanan sistem yang lebih tinggi dengan kondisi lain konstan berarti semakin besar jumlah komponen dalam fase gas, sehingga transfer massanya ke fase cair semakin besar pula. Jika tidak terjadi reaksi kimia antara komponen terabsoprsi (absorbat) dengan pengabsorpsinya (absorben) maka prosesnya disebut absoprsi fisika. Sedangkan jika terjadi reaksi kimia, maka disebut absorpsi kimia.

Di industri, proses absorpsi ini biasanya dipakai dalam proses pemisahan bahan. Absorben yang sudah menyerap absorbat kemudian diregenerasi dengan mengembalikan absorbatnya ke fase gas dengan proses yang disebut pelucutan (stripping). Proses ini dilakukan dengan memanaskan absorben yang mengandung absorbat sehingga kelarutan absorbatnya akan menurun dan berpindah ke fase gas. Biasanya dipakai kukus (steam) sebagai media pemanas dalam proses pelucutan ini. Proses absorbsi dan stripping $\mathrm{CO}_{2}$ dari gas buang hasil pembakaran ditunjukkan dalam Gambar 1. Proses ini memerlukan energi besar karena memakai kukus sebagai media pemanas.

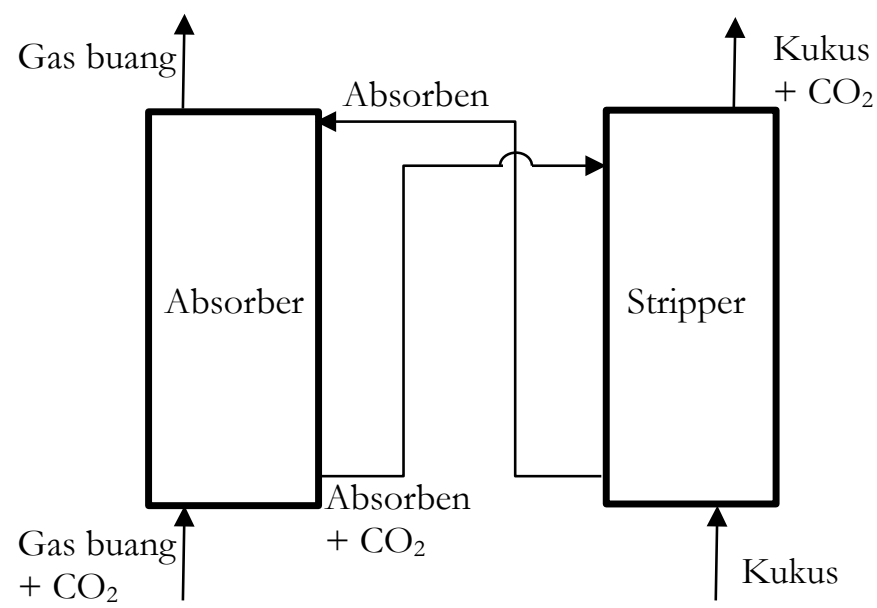

Gambar 1. Diagram absorpsi dan stripping $\mathrm{CO}_{2}$ dari gas buang.

Beberapa cara agar konsumsi energi dari proses absorpsi $\mathrm{CO}_{2}$ ini bisa dikurangi yaitu 1 . Mencari alternatif cairan atau zat absorben yang baik 2. Menggunakan kembali panas laten dari proses desorpsi. 3. Melakukan regenerasi absorben.Oleh karena itu, perlu dibahas beberapa absorben yang sering digunakan untuk penangkapan $\mathrm{CO}_{2}$ yang diharapkan bisa menurunkan konsumsi energi dan absorben mudah teregenerasi.

\subsection{Jenis - jenis absorben untuk proses absorbsi $\mathrm{CO}_{2}$}

Banyak penelitian yang sudah membahas berbagai macam absorben untuk abosrpsi $\mathrm{CO}_{2}$. Pemilihan pelarut (seperti absorben berbasis amina, garam karbonat,dan cairan ionik, dll.) adalah salah satu elemen terpenting untuk mengurangi kebutuhan energi dalam proses penyerapan $\mathrm{CO}_{2}$ dengan absorbsi kimia. Dalam beberapa tahun terakhir, pelarut yang berbeda, seperti pelarut dengan perubahan fasa dan pelarut yang dicampurkan, telah dikembangkan sebagai kandidat potensial dalam penyerapan $\mathrm{CO}_{2}[2 ; 3]$ Untuk itu perlu dicari absorben dengan kapasitas penyerapan tinggi dan konsumsi energi rendah untuk menghilangkan $\mathrm{CO}_{2}$.

Pada absorben dengan membrane berbasis grafena keunggulannya diantaranya yaitu meiliki kekuatan mekanik yang bagus, stabilitas termal yang bagus, merupakan senyawa inert sehingga tidak ada reaksi samping. Absorben membrane berbasis grafena ini sudah banyak digunakan dalam proses pemisahan gas, proses filtrasi air, proses desalinasi, dan proses pemisahan organic. Namun membrane berbasis grafena ini cukup mahal 
untuk pengoperasiannya salah satu penyebabnya yaitu sebelum bisa digunakan sebagai absorben membrane berbasis grafena ini harus di treatment terlebih dahulu[4].

Berikut ini merupakan table yang akan menjelaskan keuntungan dan kelemahan dari amine based absorben:

Tabel 1. Kelebihan dan kekurangan dari amine based absorben untuk metode penyerapan $\mathrm{CO}_{2}[5]$

\begin{tabular}{|c|c|c|c|}
\hline Tipe absorben & Nama & Keuntungan & Kerugian \\
\hline Amine Solution & MEA & Absorpsi yang cepat & $\begin{array}{l}\text { Konsusmsi energi } \\
\text { daur ulang yang tinggi } \\
\text { dan sangat mudah } \\
\text { mengalami degradasi } \\
\text { oxidatig }\end{array}$ \\
\hline Amine Solution & MDEA & $\begin{array}{l}\text { Kapasitas absorpsi } \\
\text { yang tinggi dan } \\
\text { konsumsi energi daur } \\
\text { ulang yang rendah } \\
\end{array}$ & $\begin{array}{l}\text { Kecepatan absorpsi } \\
\text { rendah }\end{array}$ \\
\hline Amine Solution & DEA & Absorpsi yang cepat & $\begin{array}{l}\text { Konsusmsi energi } \\
\text { daur ulang yang tinggi } \\
\text { dan sangat mudah } \\
\text { mengalami degradasi } \\
\text { oxidatig }\end{array}$ \\
\hline Amine solution & AMP & $\begin{array}{lr}\text { Kapasitas } & \text { dan } \\
\text { kecepatan } & \text { absorpsi } \\
\text { yang tinggi } & \\
\end{array}$ & $\begin{array}{l}\text { Mahal dan belum } \\
\text { adanya teknologi yang } \\
\text { siap menggunakannya }\end{array}$ \\
\hline Amine solution & PZ & $\begin{array}{l}\text { Kecepatan absorpsi } \\
\text { yang tinggi }\end{array}$ & $\begin{array}{l}\text { Mahal, dapat terjadi } \\
\text { korosi, dan toksisitas } \\
\text { yang tinggi }\end{array}$ \\
\hline Membranes & $\begin{array}{l}\text { Membrane berbasis } \\
\text { amine }\end{array}$ & $\begin{array}{l}\text { Untuk pemisahan } \\
\mathrm{CO}_{2}\end{array}$ & $\begin{array}{l}\text { Kecepatan absorbs } \\
\mathrm{CO}_{2} \text { nya lebih rendah } \\
\text { dari MEA }\end{array}$ \\
\hline Membranes & II-based membranes & $\begin{array}{l}\text { Dapat menurunkan } \\
\text { viskositas dari ILs }\end{array}$ & Mahal \\
\hline
\end{tabular}

Selain itu beberapa penelitian juga menambahkan pelarut pada membran. Seperti contoh nya absorben MEA ditambah dengan glycerol sebagai pelarut. Pemberian pelarut glycerol ini ternyata secara signifikan dapan meningkatkan efisiensi penghilangan $\mathrm{CO}_{2}$ dan selain itu glycerol juga merupakan pelarut yang eco-friendly. Beberapa absorben ini perlu diteliti lebih lanjut untuk mendapatkan absorben mana yang paling efektif dalam penyerapan $\mathrm{CO}_{2}[6]$.

\section{CCU dengan Mikro-alga}

Proses regenerasi absorben bisa dilakukan secara fisis dengan pelucutan (stripping) memakai kukus (steam). Namun proses ini memerlukan energi yang besar untuk produksi kukusnya. Banyak cara yang telah dilakukan untuk mengurangi pemakaian erergi ini, salah satunya dengan meniru cara kerja alam yaitu penangkapan $\mathrm{CO}_{2}$ dengan menggunakan pendekatan biologis dengan memanfaatkan dan merekayasa kemampuan pengikat $\mathrm{CO}_{2}$ bawaan dari organisme fotoautotrotrofik seperti tumubuhan dan alga. Banyak penelitian yang memanfaatkan mikro-alga untuk meregenerasi absorben, hal ini dikarenakan dari berbagai penelitian telah menunjukan bahwa mkroalga dapat menyerap $\mathrm{CO}_{2}$ hingga $20 \%$ v/v[7]. Mikro-alga ini juga dapat dengan mudah mengkonversi $\mathrm{CO}_{2}$ menjadi bahan yang bermanfaat tergantung dari jenis yang digunakan. Perlu identifikasi strain mikroalga terbaik untuk absorpsi $\mathrm{CO}_{2}$ ini sehingga dapat meminimalisir konsumsi energi dan pemanfaatan selanjutnya yang menguntungkan.

Chlorella vulgaris merupakan mikroalga yang pertama kali di kultur sepenuhnya. Memiliki bentuk spherical unicellular eukaryotic green alga yang memiliki dinding sel yang tebal $(100-200 \mathrm{~nm})$ sebagai karakteristik utama. Dinding sel ini memberikan proteksi secara mekanikal dan kemikal.Carbon capture terjadi akibat 
enzim carbonic anhydrase yang dapat mengkatalasi hidrasi dari $\mathrm{CO}_{2}$ untuk membentuk $\mathrm{HCO}$ - dan sebuah proton. Carbon fixation bergantung mainly terhadap konsentrasi $\mathrm{CO}_{2}$ dari umpan gas dan tipe reaktor.

Tipe reaktor yang cocok untuk c.vulgaris adalah membrane photobioreactors dimana saat $4 \% \mathrm{CO}_{2}$, serapan maksimum $\mathrm{CO}_{2}$ sekitar $200 \mathrm{mgL}^{-1} \mathrm{~d}^{-1}$, sedangkan saat $5 \% \mathrm{CO}_{2}$, serapan maksimum $\mathrm{CO}_{2}$ sekitar $259 \mathrm{mgL}^{-1} \mathrm{~d}^{-1}$, ada beberapa studi yang mengatakan paling optimal di $6 \%$ [8]

Scenedesmus obliquus, merupakan mikroalga uniselular hijau yang memiliki sifat seperti cblorella vulgaris. dalam kondisi yang sama, penyerapan $\mathrm{CO}_{2}$ chlorella vulgaris lebih besar disbanding Scenedesmus obliquus dengan 140.91 and $129.82 \mathrm{mg} \mathrm{L}^{-1}$ day $^{-1}$ masing - masing sedangkan, konversi biomassa ( $\mathrm{E}_{\mathrm{CO} 2}$ ) C.Vulgaris sebesar $14.9 \%$ dan S. Obliquus sebesar 13.8\%[9]

Psammothidium sp., merupakan spesies diatom yang merupakan alga uniseluler mikroskopis dengan dinding sel keras tersusun dari amorf silikat. Dinding sel diatom menunjukkan sifat morfologi yang sangat berbeda tergantung pada jenis dan kondisi kehidupan. Diperkirakan ada 100.000 spesies berbeda yang diklasifikasikan berdasarkan geometri cangkang langka. Setiap sel memiliki ukuran mulai dari 1 hingga 500 mikrometer [11]

Monoraphidium contortum adalah genus microagae di keluarga Selenastraceae..Pada strain microalga M. Contortum didapat penelitian bahwa microalgae ini termasuk salah satu yang cukup menghasilkan hasil yang memuaskan untuk absorpsi $\mathrm{CO}_{2}$. M. Contortum akan bertransformasi menjadi biodiesel dengan kulaitas yang memadai. Lipid diubah menjadi biodiesel yang diperoleh dari minyak $\mathrm{m}$. contortum adalah asam oleat dan asam palmitat. Peningkatan $\mathrm{CO}_{2}$ yang progresif, memungkinkan hasil dan produktivitas lipid yang lebih tinggi oleh M. contortum[10]. Untuk menentukan apakah Monoraphidium sp. akan menjadi kandidat spesies unggul untuk digunakan dalam produksi biofuel harus sesuai dengan pemrosesan menjadi biodiesel, yang melibatkan pemanenan, produksi dan ekstraksi lipid, dan konversi lipid. Pada penelitian disimpulkan bahwa Organisme ini toleran terhadap dingin dan melakukan bioremediasi air limbah sambil memproduksi lipid.Kultur mesokosmos menunjukkan bahwa sel akan beradaptasi dengan baik pada produksi skala besar.Biodiesel alga dari Monoraphidium menghasilkan emisi NOx yang rendah selama engine test[12].

Dunaliella sp. adalah uniseluler biflagellate ganggang hijau. Sllnya berbentuk bulat dapat ditemukan dalam lingkungan brackish. Dunailiella sp. Mempunyai toleransi tinggi tergadap suhu, garam, dan cahaya. Spesies ini juga relatif mudah dibudidayakan. Sel membelah dengan pembelahan biner sederhana dan telah diamati tidak ada bukti sel lisi atau pembentukan spora. Dunailiella sp. dapat tumbuh subur pada rentang $\mathrm{pH}$ yang luas . Dunaliella merupakan mikroalga penting untuk proses industri karena menghasilkan berbagai macam produk komersial (terutama pigmen) dan pemecahan sel yang sangat mudah.

Spesies Nannochloropsis telah muncul sebagai spesies potensial untuk produksi biomassa dan lipid dengan persentase $\mathrm{CO}_{2}$ yang tinggi. Nannochloropsis berasal dari laut. Nannochloropsis sp. menunjukkan tingkat penyerapan $\mathrm{CO}_{2}$ yang tinggi sebesar $0,42 \mathrm{~g} \mathrm{CO}_{2}$ yang diserap per gram biomassa per jam ( $\mathrm{g} / \mathrm{g} / \mathrm{jam}$ ) ketika dibudidayakan dalam fotobioreaktor tangki berpengaduk yang dimodifikasi [13]. N. oculata dapat dibudidayakan dalam media Conway yang dimodifikasi dalam kondisi kekurangan nutrisi $\mathrm{N}$ untuk mendukung akumulasi lipid.

\section{CCU kombinasi Absorbsi dan Mikro-Alga}

Kombinasi proses (hybrid) dari proses absorpsi dan proses mikro-alga untuk penangkapan $\mathrm{CO}_{2}$ menarik perhatian karena dapat menjadi solusi untuk mengatasi kelemahan masing-masing proses sehingga terbentuk proses yang lebih efektif. Bikarbonat adalah medium yang ideal untuk megabungkan proses absorpsi dan budidaya mikroalga. Bikarbonate adalah produk dominan yang dihasilkan dari reaksi absorpsi yang merupakan sumber nutrisi untuk pertumbuhan mikroalga. Mikroalga memiliki potensi untuk menghilangkan $\mathrm{CO}_{2}$ terlarut dari pelarut absorben dengan menggunakan energi matahari. Setelah itu, ketika bikarbonate telah digunakan oleh mikroalga, larutan absorben dapat diregenerasi menadi karbonat atau alkanoalamin, dan kemudian didaur ulang menjadi penyerap untuk menangkap $\mathrm{CO}_{2}$ berikutnya [14]. Selain itu, karbon dapat diubah atau diproses lebih lanjut oleh mikro alga menjadi biomassa yang bermanfaat (misalnya biofuel,polisakarida,protein,pigmen, dll.), hal ini meningkatkan keuntungan untuk aplikasi komersial[15].

Tabel berikut akan menjelaskan keuntungan dan tantangan dalam proses hybrid penangkapan $\mathrm{CO}_{2}$ hasil penelitian.

Mini-Review Teknologi Carbon Capture and Utilization (CCU) Berbasis Kombinasi Proses 
Tabel 2. Keuntungan dan tantangan dari proses hybrid penyerapan dan pemanfaatan $\mathrm{CO}_{2}$

\begin{tabular}{|c|c|c|c|c|c|}
\hline Proses Hybrid & $\begin{array}{l}\text { Efisiensi } \\
\text { Karbon } \\
\text { fiksasi (\%) }\end{array}$ & $\begin{array}{c}\text { Produktifitas } \\
\text { Biomass } \\
\text { (mg.L-1.d-1) }\end{array}$ & Keuntungan & Tantangan & Ref. \\
\hline MEA + Spirulina & 16 & 62.1 & $\begin{array}{l}\text { - Penambahan } \\
\text { MEA dan recycle } \\
\text { dari medium } \\
\text { dapat mendorong } \\
\text { lebih banyak } \\
\text { pertumbuhan dan } \\
\text { biomassa yang } \\
\text { dihasilkan lebih } \\
\text { banyak } 31.4 \% \\
\text { - Kandungan } \\
\text { karbohidrat } \\
\text { hampir } 96.0 \% \\
\text { lebih tinggi }\end{array}$ & $\begin{array}{l}\text { - Konsentrasi } \\
\text { protein rendan }\end{array}$ & [16] \\
\hline $\begin{array}{l}\text { DEA/K2CO3 + } \\
\text { Spirulina }\end{array}$ & 43.7 & 174.2 & $\begin{array}{l}\text { - Meningkatkan } \\
\text { konsentrasi } \\
\text { karbon anorganik } \\
\text { terlarut dalam } \\
\text { media budidaya } \\
\text { (hingga } 450 \mathrm{mg} \mathrm{L-} \\
\text { 1) } \\
\text { - Peningkatan laju } \\
\text { fiksasi } \mathrm{CO}_{2} \text { dan } \\
\text { produktivitas } \\
\text { biomassa }(174,2 \\
\text { mg } \mathrm{L}-1 \cdot \mathrm{d}-1) \\
\text { - Kandungan } \\
\text { protein tinggi } \\
(58,8 \% \mathrm{w} \cdot \mathrm{w}-1) \\
\text { dan meningkatkan } \\
\text { konsentrasi } \\
\text { karbohidrat }\end{array}$ & $\begin{array}{l}\text { - Proses } \\
\text { mekanisme yang } \\
\text { kurang jelas } \\
\text { tentang kinerja } \\
\text { absorbennya di } \\
\text { dalam struktur } \\
\text { seluler mikroalga }\end{array}$ & [17] \\
\hline $\begin{array}{l}\text { MEA/AMP/DEA } \\
\text { /TEA + } \\
\text { Scenedesmus sp. }\end{array}$ & 40 & 664.4 & $\begin{array}{l}\text { - Peningkatan } \\
\text { kandungan } \\
\text { karbon anorganik } \\
\text { terlarut (hingga } 22 \\
\text { mg L-1) } \\
\text { - Peningkatan laju } \\
\text { fiksasi } \mathrm{CO}_{2} \\
\text { (hingga 991.8 mg } \\
\mathrm{CO}_{2} \text {.L-1.d-1) }\end{array}$ & $\begin{array}{l}\text { - Penghambatan } \\
\text { pertumbuhan sel } \\
\text { karena } \\
\text { pembentukan } \\
\text { anatara karbamat } \\
\text { yang relaif stabil }\end{array}$ & [18] \\
\hline $\begin{array}{l}\mathrm{NaHCO} / \mathrm{Na} 2 \mathrm{C} \\
\text { O3 } \\
\text { Cyanobacterium }\end{array}+$ & - & 1210 & $\begin{array}{l}\text { - Fotobioreaktor } \\
\text { sederhana tanpa } \\
\mathrm{CO}_{2} \text { sparging } \\
\text { - Pasokan karbon } \\
\text { anorganik yang } \\
\text { cukup sudah } \\
\text { dalam bentuk }\end{array}$ & $\begin{array}{l}\text { - Strain harus } \\
\text { memiliki toleransi } \\
\text { tinggi pada ion } \\
\text { dan alkalinitas } \\
\text { - Tingkat } \\
\text { pertumbuhan } \\
\text { lambat }\end{array}$ & [19] \\
\hline
\end{tabular}




\begin{tabular}{|c|c|c|c|c|c|}
\hline Proses Hybrid & $\begin{array}{c}\text { Efisiensi } \\
\text { Karbon } \\
\text { fiksasi (\%) }\end{array}$ & $\begin{array}{c}\text { Produktifitas } \\
\text { Biomass } \\
\text { (mg.L-1.d-1) }\end{array}$ & Keuntungan & Tantangan & Ref. \\
\hline & & & $\begin{array}{l}\text { bikarbonat bukan } \\
\mathrm{CO}_{2} \\
\text { - Regenerasi } \\
\text { karbonat melalui } \\
\text { mikroalga } \\
\text { digunakan untuk } \\
\text { menyerap } \mathrm{CO}_{2} \\
\text { berikutnya }\end{array}$ & $\begin{array}{l}\text { - Tingkat } \\
\text { kehilangan } \mathrm{CO}_{2} \\
\text { tinggi }\end{array}$ & \\
\hline $\begin{array}{l}\mathrm{NH} 4 \mathrm{HCO} 3 \\
\text { Chlorella variabilis }\end{array}$ & - & 296.33 & $\begin{array}{l}\text { - Produksi } \\
\text { biomassa dan lipid } \\
\text { yang lebih tinggi } \\
\text { dalam waktu } \\
\text { produksi yang } \\
\text { lebih singkat } \\
\text { - Kandungan gula } \\
\text { pereduksi lebih } \\
\text { tinggi }(14.25 \%) \\
\text { - Amonium } \\
\text { bikarbonat } \\
\text { dihasilkan sebagai } \\
\text { limbah mentah } \\
\text { dari industri } \\
\text { pigmen }\end{array}$ & $\begin{array}{l}\text { - Meningkatkan } \\
\text { pH } \\
\text { - } \mathrm{NH}_{3} \text { hilang }\end{array}$ & [20] \\
\hline $\begin{array}{l}\text { NaHCO3 } \\
\text { Chlorella }\end{array}$ & - & - & $\begin{array}{l}\text { - } \text { Mendorong } \\
\text { pertumbuhan } \\
\text { mikroalga dan } \\
\text { produksi lipin } \\
\text { - Agen antibakteri }\end{array}$ & $\begin{array}{l}\text { - Mekanisme } \\
\text { kontaminasi } \\
\text { bakteri yang tidak } \\
\text { jelas dalam } \\
\text { konsentrasi } \\
\text { bikarbonat yang } \\
\text { tinggi di } \\
\text { mikroalga } \\
\text { medium }\end{array}$ & [21] \\
\hline $\begin{array}{l}\text { NaHCO3 } \\
\text { Dictyosphaerium } \\
\text { sp }\end{array}$ & - & - & $\begin{array}{l}\text { - Hasil biomassa } \\
\text { meningkat lebih } \\
\text { dari empat kali } \\
\text { lipat } \\
\text { - Efisiensi } \\
\text { pemanfaatan } \\
\text { bikarbonat } \\
\text { meningkat lebih } \\
\text { dari tiga kali }\end{array}$ & $\begin{array}{l}\text { - Diperlukan } \\
\text { konsentrasi } \mathrm{Na}+ \\
\text { yang rendah } \\
\text { - } \mathrm{pH} \text { peerlu } \\
\text { dikontrol }\end{array}$ & [22] \\
\hline $\begin{array}{l}\text { NaHCO3 } \\
\text { Dunaliella salina }\end{array}$ & 91.40 & - & $\begin{array}{l}\text { - Tingkat } \\
\text { pertumbuhan } \\
\text { spesifik } 2.84 \text { kali } \\
\text { lipat lebih tinggi } \\
\text { daripada kontrol } \\
\text { bebas bikarbonat } \\
\text { - Produktivitas } \\
\text { biomassa serupa }\end{array}$ & $\begin{array}{l}\text { - Metode yang } \\
\text { ekonomis dalam } \\
\text { memproduksi } \\
\text { bikarbonat } \\
\text { - } \mathrm{pH} \text { perlu } \\
\text { dikontrol }\end{array}$ & [23] \\
\hline
\end{tabular}

Mini-Review Teknologi Carbon Capture and Utilization (CCU) Berbasis Kombinasi Proses 


\begin{tabular}{|c|c|c|c|c|c|}
\hline Proses Hybrid & $\begin{array}{c}\text { Efisiensi } \\
\text { Karbon } \\
\text { fiksasi (\%) }\end{array}$ & $\begin{array}{c}\text { Produktifitas } \\
\text { Biomass } \\
\text { (mg.L-1.d-1) }\end{array}$ & Keuntungan & Tantangan & Ref. \\
\hline & & & $\begin{array}{l}\text { dengan sistem } \\
\text { berbasis } \mathrm{CO}_{2} \\
\text { - Efisiensi } \\
\text { pemanfaatan } \\
\text { karbon tinggi } \\
(91.40 \%)\end{array}$ & & \\
\hline $\begin{array}{l}\text { DEA } \\
\text { Chlamydomonas / } \\
\text { Chlorella/ } \\
\text { Pseudochlorococc } \\
\text { um }\end{array}$ & - & - & $\begin{array}{l}\text { - } \text { regenerasi larutan } \\
\text { membutuhkan } \\
\text { energi yang jauh } \\
\text { lebih rendah } \\
(85 \%) \\
\text { - BIomassa dapat } \\
\text { digunakan untuk } \\
\text { memproduksi } \\
\text { hasil yang } \\
\text { berharga seperti } \\
\text { lipid, protein, dan } \\
\text { pigmen }\end{array}$ & $\begin{array}{l}\text { - Kehilangan DEA } \\
\text { - Tingkat } \\
\text { pertumbuhan } \\
\text { rendah } \\
\text { - Efisiensi konversi } \\
\text { karbon yang } \\
\text { terbatas }\end{array}$ & {$[24]$} \\
\hline
\end{tabular}

\section{Kesimpulan}

Dari literatur yang telah dipelajari bisa disimpulkan bahwa teknologi carbon capture dengan absorbsi kimia dan regenerasi absorbennya secara biologi dengan mikro alga sangat potesial untuk diteliti dan dikembangkan. Regenerasi absorben menggunakan mikro alga bisa memanfaatkan energi dari sinar matahari sehingga tidak menambah emisi karbon di atmosfer. Sedangkan mikro alga yang diproduksi berpotensi menjadi bahan baku berbagai produk yang bermanfaat. Tantangan yang masih harus dipecahkan di antaranya adalah kecepatan reaksi bioproses konversi karbon oleh mikro alga yang tidak bisa secepat proses kimia di absorber. Perlu optimisasi agar proses yang cepat di absorber dapat diimbangi dengan reaksi bioproses oleh mikro alga.

\section{Referensi}

[1] J. Tollefson, "How hot will Earth get by 2100?," Nature, vol. 580, no. 7804, pp. 443-445, 2020, doi: 10.1038/d41586-020-01125-x.

[2] Liang, Z., Fu, K., Idem, R., Tontiwachwuthikul, P., 2016. Review on current advances future challenges and consideration issues for post-combustion CO2 capture using amine-based absorbents. Chin. J. Chem. Eng. 24, 278-288

[3] Zhang, K., Liu Z., Wang, Y., Li, Y., Li, Q., Zhang, J., Liu, H., 2014, Flash evaporation and thermal vapor compression aided energy saving $\mathrm{CO} 2$ capture systems in coal-fixed power plant. Energy 66, 556-568

[4] A. Ali, R. Pothu, S. H. Siyal, S. Phulpoto, M. Sajjad, and K. H. Thebo, "Graphene-based membranes for CO2 separation,” Mater. Sci. Energy Technol., vol. 2, no. 1, pp. 83-88, 2019, doi: 10.1016/j.mset.2018.11.002.

[5] C. H. Yu, C. H. Huang, and C. S. Tan, "A review of CO2 capture by absorption and adsorption," Aerosol Air Qual. Res., vol. 12, no. 5, pp. 745-769, 2012, doi: 10.4209/aaqr.2012.05.0132.

[6] P. Valeh-e-Sheyda and J. Barati, "Mass transfer performance of carbon dioxide absorption in a packed column using monoethanoleamine-Glycerol as a hybrid solvent," Process Saf. Environ. Prot., vol. 146, pp. 54-68, 2021, doi: 10.1016/j.psep.2020.08.024.

[7] R. Verma and A. Srivastava, "Carbon dioxide sequestration and its enhanced utilization by photoautotroph microalgae,” Environ. Dev., vol. 27, no. October 2017, pp. 95-106, 2018, doi: 10.1016/j.envdev.2018.07.004. 
[8] Sydney, Eduardo B., Alessandra Cristine Novak Sydney, Júlio Cesar de Carvalho, Carlos Ricardo Soccol,2019. Chapter 4 - Potential carbon fixation of industrially important microalgae,67-88. https://doi.org/10.1016/B978-0-444-64192-2.00004-4.

[9] Chaudhary, Ramjee \& Dikshit, A. \& Tong, Yen. (2018). Carbon-dioxide Biofixation and Phycoremediation of Municipal Wastewater using Chlorella vulgaris and Scenedesmus obliquus. Environmental Science and Pollution Research. 25. 10.1007/s11356-017-9575-3.

[10] G. Pineda-Camacho, F. de M. Guillén-Jiménez, A. Pérez-Sánchez, L. M. Raymundo-Núñez, and G. Mendoza-Trinidad, "Effect of CO2 on the generation of biomass and lipids by Monoraphidium contortum: A promising microalga for the production of biodiesel," Bioresour. Technol. Reports, vol. 8, no. July, 2019, doi: 10.1016/j.biteb.2019.100313.

[11] Aghaalipour, E., Aydın Akbulut, Gülen Güllü, (2020) Carbon dioxide capture with microalgae species in continuous gas-supplied closed cultivation systems, Volume 163, https://doi.org/10.1016/j.bej.2020.107741.

[12] G. P. Holbrook, Z. Davidson, R. A. Tatara, N. L. Ziemer, K. A. Rosentrater, and W. Scott Grayburn, "Use of the microalga Monoraphidium sp. grown in wastewater as a feedstock for biodiesel: Cultivation and fuel characteristics," Appl. Energy, vol. 131, pp. 386-393, 2014, doi: 10.1016/j.apenergy.2014.06.043.

[13] R. Verma, R. Kumar, L. Mehan, and A. Srivastava, "Modified conventional bioreactor for microalgae cultivation," J. Biosci. Bioeng., vol. 125, no. 2, pp. 224-230, 2018, doi: 10.1016/j.jbiosc.2017.09.003.

[14] Z. Chi, Y. Xie, F. Elloy, Y. Zheng, Y. Hu, and S. Chen, "Bicarbonate-based Integrated Carbon Capture and Algae Production System with alkalihalophilic cyanobacterium," Bioresour. Technol., vol. 133, pp. 513-521, 2013, doi: 10.1016/j.biortech.2013.01.150.

[15] C. Song et al., "Absorption-microalgae hybrid CO2 capture and biotransformation strategy-A review," Int. J. Greenh. Gas Control, vol. 88, no. April, pp. 109-117, 2019, doi: 10.1016/j.iiggc.2019.06.002.

[16] G. M. da Rosa, L. Moraes, B. B. Cardias, M. da R. A. Z. de Souza, and J. A. V. Costa, "Chemical absorption and CO2 biofixation via the cultivation of Spirulina in semicontinuous mode with nutrient recycle," Bioresour. Technol., vol. 192, pp. 321-327, 2015, doi: 10.1016/j.biortech.2015.05.020.

[17] B. B. Cardias, M. G. de Morais, and J. A. V. Costa, "CO2 conversion by the integration of biological and chemical methods: Spirulina sp. LEB 18 cultivation with diethanolamine and potassium carbonate addition," Bioresour. Technol., vol. 267, no. June, pp. 77-83, 2018, doi: 10.1016/j.biortech.2018.07.031.

[18] G. Kim, W. Choi, C. H. Lee, and K. Lee, "Enhancement of dissolved inorganic carbon and carbon fixation by green alga Scenedesmus sp. in the presence of alkanolamine CO2 absorbents," Biochem. Eng. J., vol. 78, pp. 18-23, 2013, doi: 10.1016/j.bej.2013.02.010.

[19] Chi, Z., Xie, Y., Elloy, F., Zheng, Y., Hu, Y., \& Chen, S. (2013). Bicarbonate-based Integrated Carbon Capture and Algae Production System with alkalihalophilic cyanobacterium. Bioresource Technology, 133, 513-521. https://doi.org/10.1016/j.biortech.2013.01.150

[20] Bhattacharya, S., Soundarya, R., Mishra, S., 2016. Ammonium bicarbonate as nutrient substitute for improving biomass productivity of Chlorella variabilis. Chem. Eng. Technol. 39, 1738-1742

[21] Z. Tu, L. Liu, W. Lin, Z. Xie, and J. Luo, "Potential of using sodium bicarbonate as external carbon source to cultivate microalga in non-sterile condition," Bioresour. Technol., vol. 266, no. June, pp. 109_ 115, 2018, doi: 10.1016/j.biortech.2018.06.076.

[22] Cheng, Q., Xu, L, Cheng, F., Pan, G., Zhou, Q., 2018. Bicarbonate-rich wastewater as a carbon fertilizert for culture of Dictuopsphaerium sp. of a giant pyrenoid. J. Clean. Prod. 202, 439-443.

[23] G. Y. Kim, J. Heo, H. S. Kim, and J. I. Han, "Bicarbonate-based cultivation of Dunaliella salina for enhancing carbon utilization efficiency," Bioresour. Technol., vol. 237, pp. 72-77, 2017, doi: 10.1016/j.biortech.2017.04.009.

[24] Al-Zuhair, S., Alketbi, S., Al-Marzouqi , M., 2016. Regenerating diethanolamine aqueous solution for CO2 absorption using microalgae. Ind BIotechnol. 12, 105-108. 
